\title{
READINGS OF INDONESIAN CHRISTIANS ON MOSES AND SOME SIGNIFICANT NOTES ON POLITICS OF IMAGERY IN INDONESIAN
}

\author{
Fredrik Y. A. Doeka \\ Lecturer of Islam and Theology of Religions \\ at the Theological Faculty UKAW Kupang, \\ email: fredrikyadoeka@yahoo.co.uk
}

\section{ABSTRAK}

Kristen memandang Musa sebagai salah satu pendahulu terbesar dari tokoh sentral dari agama mereka, di samping Yesus. Musa tidak hanya nenek moyang dan pendahulu, tetapi sebagai bagian model dalam kehidupan Isa. Injil Matius memiliki banyak referensi yang menunjukkan Musa sebagai model untuk Jesus. Musa tidak menjadi isu utama dalam perdebatan modern, oleh karena itu sulit untuk memilih satu atau beberapa ide sentral yang berhubungan dengan Musa. Meskipun demikian, artikel ini mencoba untuk menguraikan posisi Musa sebagai pemimpin yang disajikan oleh para teolog kontemporer di Indonesia. Bagaimana mereka mendiskusikan tentang Musa sebagai pihak yang relevan terkait dengan perjuangan politik di Israel. Untuk kepentingan artikel ini, saya fokus pada pada pandangan Emmanuel Gerrit Singgih, Sri Wismoady Wahono, Eben Nuban Timo, Thomas Aquino Deshi Ramadhani, Martin Harun Olsthoorn, dan YM Seto Marsunu. Berdasarkan bacaan mereka, saya akan memberikan beberapa catatan penting dalam kaitannya dengan politik pencitraan di Indonesia.
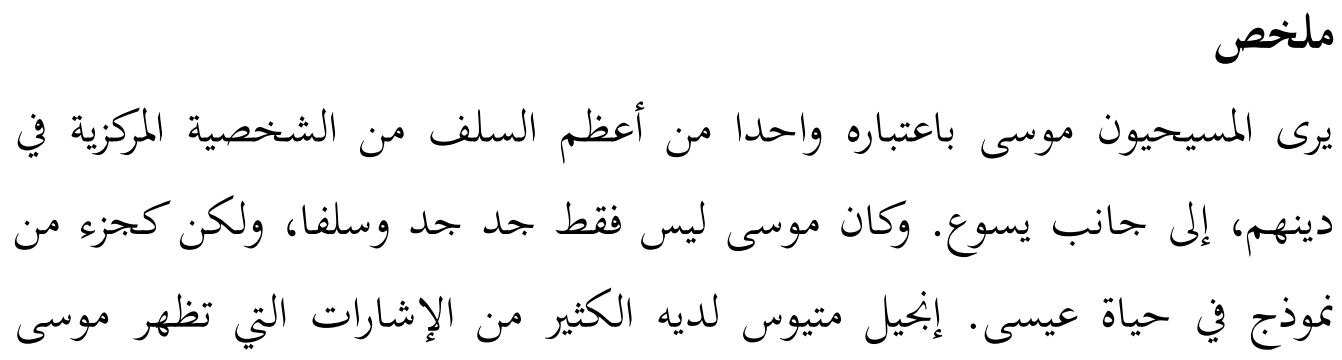

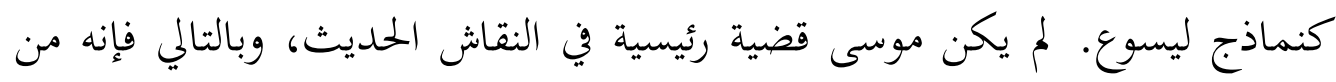

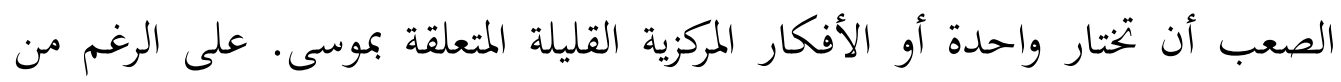




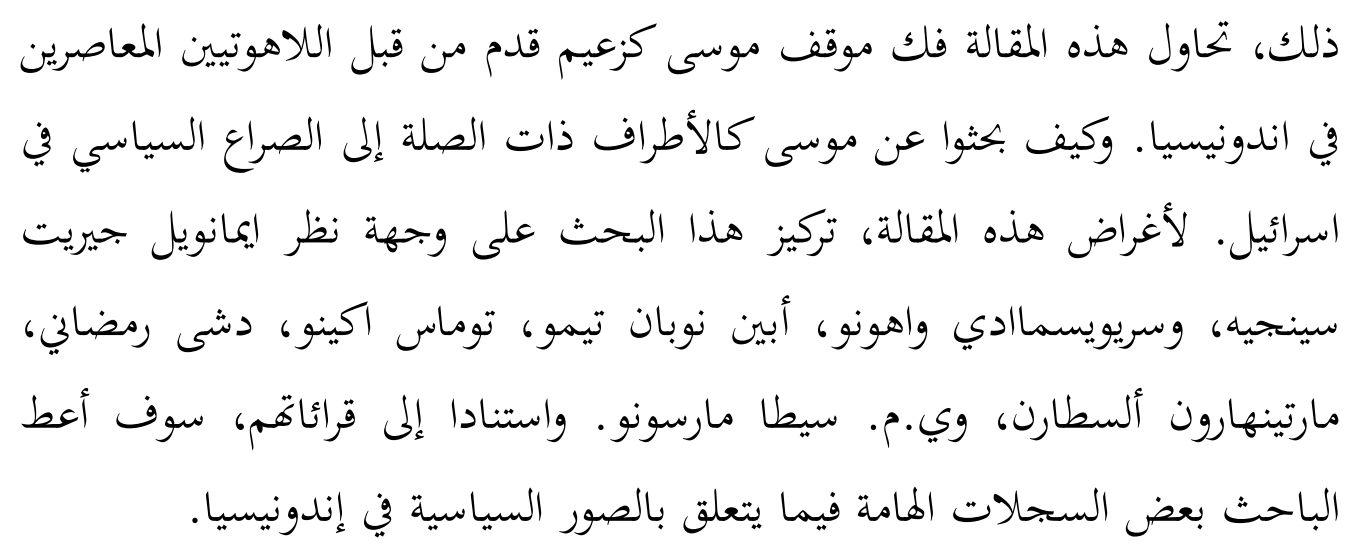

Key words: Moses, christian, politic, Indonesia

\section{A. Emmanuel Gerrit Singgih: Lessons from a Moses who is imperfect}

Emmanuel Gerrit Singgih is a minister of the Protestant Church in the Western part of Indonesia (Gereja Protestan Indonesia di Bagian Barat, GPIB) and a professor of the Theological Department of Duta Wacana Christian University, Yogyakarta. He obtained his Ph.D. in Old Testament Studies at GlasgowUniversity in 1982 with a dissertation From Israel to Asia. Besides his major position at the Protestant Duta Wacana, he also teaches at the Theological Faculty of Sanatha Dharma Catholic University and the Graduate Program of Cross-Cultural and Religious Studies (CRCS) of Gajah Mada University. He has written many books and articles which became important references for theology students, ministers, and theologians in Indonesia. An English translation of selected articles was published as Doing Theology in Indonesia; Sketches for an Indonesian Contextual Theology (2003).

In 2004, during the period of Reformasi after the abdication of the autocratic President Suharto (1966-1998), Singgih wrote a remarkable and critical study on the strong and weak sides of Moses. Singgih compared Moses' life with that of Soekarno, the founder and first president of Indonesia, 1945-1966, who was sometimes not less dictatorial and dominant than his successor Suharto. Singgih states that there are significant similarities between Moses and Soekarno. In 
doing their tasks, each of them had two close partners. Aaron and Miriam were partners and also helpers for Moses, while Soekarno had Muhammad Hatta as vice-president of Indonesia and Sutan Syahrir as prime minister.

Their marriage records also show remarkable similarities. They married more than once and their marriages were criticized by their close partners. Moses was in conflict with Aaron and Miriam because he married a Cushite. "Miriam and Aaron began to talk against Moses because of his Cushite wife, for he had married a Cushite" (Numbers 12:1). Miriam and Aaron disagreed with Moses because he committed a crime by this marriage to a Cushite. Moses' marriage to a Cushite was against the religious law that banned anyone who was in intimate alliance with foreigners. Singgih states that if Moses disobeyed the law, his power and authority should become questionable. Miriam and Aaron felt guilty because of the deed of their younger brother, Moses. As siblings of Moses, they also had right to be mediators between God and the Israelites. So if one of them disobeyed the revelation, the others had to advise him or her in order to be loyal to the law. That is why Miriam criticized her younger brother by saying: "Has the Lord spoken only through Moses? ... Hasn't He also spoken through us?" (Numbers 12:2). ${ }^{1}$ While mentioning the case of Soekarno, Singgih gives no detailed explanation. But he knows surely that Soekarno had met a Japanese woman Nemoto Naoko (later called Ratna Sari Dewi) during a state visit to Japan and then married the nineteen year old woman. This woman who was married to Soekarno as his fifth wife, was an art student and entertainer. There were rumours of her work as a geisha (female entertainer) and this became a controversial issue in Indonesia.

The next dramatic episode is the punishment of Miriam because she spoke against (Indonesian: mengatai) Moses who was a servant of God (cf. Numbers 12:1). The term 'servant of God' was applied to a collective entity (Isaiah 40-55) after the period of Exile, but it was a special personal attribute given to Moses in Exodus. It indicates that Moses had a close relationship with God and therefore the Lord relied on him more than on others. But in this privileged position Moses acted alone and refused partnership in leadership.For Singgih, the claim that not only Moses but also Miriam and Aaron could be mediators between God and the Israelites is interpreted as a strong criticism to the sole leader-

1 Singgih 2004:19. 
ship of Moses (Numbers 12:2). ${ }^{2}$ Korah, Dathan and Abiram also criticized Moses by questioning why he raised himself to rule Israel (Numbers 16:3). However, their opposition to Moses as the servant of God caused God to punish them. Soon after this revolt the ground beneath them split open and swallowed them alive with all their possessions (Numbers 16: 31-32). The cases above stifled all criticisms to Moses and even strengthened his position as sole political leader, similar to that of Soekarno, who named himself pemimpin besar revolusi (the Great Leader of the Revolution), and sacked and imprisoned the Prime Minister SutanSahrir.Soekarno also secretly pushed Muhammad Hatta to resign as vice president. ${ }^{3}$

Singgih also analyses a surprising attitude in Moses in the episode of power sharing with seventy elders of the Israelites. This story shows how Moses wanted to share his power with other people. The seventy elders were filled with the Spirit of God at an inauguration process. Eldad and Medad, listed among the group of the seventy elders, were still outside the Meeting Tent but they too were filled with the divine spirit. For Joshua, the event was so unusual that he questioned Moses about it. But Moses' sarcastic reaction toward him was strange. Moses said to him: "Are you jealous for my sake?" This underlines the interpretation that Moses did not object to a broader divine revelation nor felt threatened with that event. He even said again: "I wish that all the Lord's people were prophets and that the Lord would put His spirit on them!" (Numbers 11:29). About this verse, Singgih states that Moses behaved or potrayed himself like an egalitarian person who required many partners to lead his people. Moreover, he encouraged other people to be prophets. From this attitude of Moses it may be concluded that the prophetical status was neither a threat nor an impediment that made it difficult for Moses to function as a political leader. In other words, as Singgih sees, Moses is not bothered by the status of the elders because he feels already secure with his position as a servant of God. ${ }^{4}$ This is in fact what was behind the permissive attitude of Moses. On the one hand he allowed sharing of power and authority with others, but on the other hand he himself stuck to his position as the servant of God with all its 'arrangements'

2 Singgih 2004:20.

3 Singgih 2004:17.

4 Singgih 2004:21. 
or 'rules'. With this position, he still kept the reins of power and authority over his people. ${ }^{5}$ This is similar to the position of Soekarno who proposed a system of 'guided democracy'. Within this system, a government was ideally based not only on political parties but also on 'functional groups' composed of the nation's basic elements, in which a national consensus is reached only under the guidance of president Soekarno.

Although Moses was imperfect in nature, he is acknowledged to have possessed a stronger faith than the other Israelites. He also performed a number of signs among the Israelites so that they undoubtedly accepted and appreciated him as an important figure in their history and religion. ${ }^{6}$ The description provided so far has indicated that both Moses and Soekarno devoted their entire lives to their people and even released their people from oppression. Moses delivered his people from the enslavement of Egypt, while Soekarno liberated Indonesians from the colonization of Japan and the Dutch. The same is done by the people of Indonesia who greatly appreciates Soekarno and remember him as the founding father of the Indonesian state.

\section{B. Singgih: Soeharto is similar to the Egyptian food.}

In his book Doing theology in Indonesia, Singgih develops a bible study on the economics of food with examples from Exodus 16. Because of the harsh condition in the desert Moses' people remembered Egyptian meat and bread. They complained to Moses and Aaron and said: "If only we had died by the Lord's hand in Egypt! There we sat around pots of meat and ate all the food we wanted, but you have brought us out into this desert to starve this entire assembly to death" (Exodus 16:3). Singgih sees the complainers as those who formerly collaborated and became agents of Pharaoh and his followers when they were in Egypt. Facing the situation, people in general remember the happiness of their past as something better than the present. Singgih compares it to the period of the reformation in Indonesia after Soeharto's fall in 1998. A few years later many people wanted Soeharto back, like the people of Moses who asked for

\footnotetext{
5 Singgih 2004:21.

6 Singgih 2004:18.
} 
Egyptian food when they were in the desert. ${ }^{7}$ Moses' people then were eating manna from heaven, but they wished to eat the food of Egypt. Although the Israelites were wandering in the wilderness, they were economically still oppressed by Egypt. Therefore, he writes:

If you want to be free, do not eat the food of those who are more powerful than you. If you have been eating sago, do not change it to rice because then you will be controlled by those who eat rice. If you have been eating rice, do not change it to noodles or bread because then you will be controlled by those who eat noodles and bread .... ${ }^{8}$

\section{Sri Wismoady Wahono: Moses as an important figure in the history and religion of Israel}

Sri Wismoady Wahono (1944-2002) was professor in Old Testament studies in the Jakarta Theological Seminary (Sekolah Tinggi Teologi Jakarta - STT Jakarta) for some years until the Synod of his church, the East Java Protestant Church [Gereja Kristen Jawi Wetan - GKJW] asked him to become its moderator. Throughout his career, he was involved in Muslim- Christian dialogues in East Java. His major academic work is an introduction to biblical studies Di Sini Ku temukan[Here I found, 1986].

In an article of 2001 Sri WismoadyWahono begins by stating that Moses is the most important figure in the history and religion of Israel. He is a perfect prophet, God's servant, and mediator between God and Israelites (Numbers 12:1-5; Deuteronomy 18:15-22). In general, he is known as the author and his name is attached to the five first books of the Old Testament, i.e. Genesis, Exodus, Leviticus, Numbers, and Deuteronomy that describe a series of events both miraculous and natural. In relation to these events, Wahonorealises that many scholars are still debating whether the events really happened in history or not. The debate, however, never damaged the admiration of the Israelites for their great prophet who played an important role in the episodes of the burning bush, the liberation of the Israelites from Egypt, the exodus, God's covenant at Mount Sinai, and the forty-year travelling in desert that reached its peak

7 Singgih 2003:24.

8 Singgih 2003:25. 
in the story of the bronze snake (Numbers 21:4-9). In the final episode, that is preceding his passing away on MountNebo, God showed Moses the Promised Land and sentenced him to death (Deuteronomy 34). Theologically, as Wahono points out, we also have to be convinced like the Israelites that all the events in the five books of Moses are God's works. ${ }^{9}$

Non-biblical sources, as Wahono states, have proved the truth of biblical stories of Moses and his people. A Hebrew source connects Moses' name mōse, with mashah, meaning 'draw out' (Deuteronomy 2:10). Etymologically, however, the word is Egyptian, meaning '(is) born' and is familiar to such names as Thutmosis, meaning 'born from Thut' and Ramesses, meaning 'born from Ra.' Besides this, Egyptian documents of the $13^{\text {th }}$ century mention the Apiru people who seemingly had a close relation to the Hebrews who made a number of royal projects in Egypt. ${ }^{10}$ And there was a group of Israelites, Habiru people, who had stayed in the Promised Land since the $15^{\text {th }}$ B.C.E. before the Apiru people from Egypt came and occupied the same Promised Land. This group never went to Egypt nor experienced the event of the exodus. But then they joined the Apiru people led by Moses, which entered Canaan at the end of the $13^{\text {th }}$ century B.C.E. The documents also declare that Pharaoh Maremptah (=Ramesses) occupied the land of Canaan and built his tower of victory in 1220 B.C.E. There is a note in the documents indicating that one of the nations defeated by Maremptah is Israel. ${ }^{11}$ Wahono does not explain it in detail whether or not Moses also led Israel as a united nation between the exodus of the Apiru and the defeat of the Habiru by Maremptah.

The documents mentioned above are in some respects ambiguous, but according to Wahono, they have no power to silence the witness of the Old Testament which proclaims that Moses lived in the palace of Egypt, but grew up with a Hebrew character and personal identity. As Wahono states, Moses' Hebrew character and personal identity even grew stronger when he began believing in God who called him and introduced Himself to him as Yahveh, meaning 'I am

\footnotetext{
9 Wahono 2001:100-1001.

10 Wahono 2001:102.

11 Wahono 2001:104.
} 
who I am', in the burning bush. Knowing that it was God who was introducing Himself to him, he felt very fearful because he recalled the murder of an Egyptian that he committed in his hometown (Exodus 4; cf. Isaiah 6; Jeremiah 1). However, the theophany encouraged and empowered him so continuously that his faith grew stronger than before. And the name of Yahveh with its power and authority always endorsed and supported him (Exodus 3:12). ${ }^{12}$

Moses taught the Israelites to understand all events that happened among them as God's deeds. Nevertheless, Wahono asserts that some of the events were Moses' own deeds. Concerning God's deeds, these can be seen in, for instance, one of the old Jahvist (J) sources. It writes: "all that night the Lord drove the sea back with a strong east wind and turned it into dry land" (Exodus 14:21). For this event, Wahono cites Miriam (Moses' older sister), stating that it is really done by God, not Moses (cf. Exodus 15:21), because Moses has no capacity to do that sign. ${ }^{13}$ The next example is at Sinai, where Moses only acted as a mediator between God and the Israelites, when God's covenant was given. Wahono, however, supposes that it was Moses who created the covenant using literary materials available at that time. The reason is because the materials of the Ten Commandments (Decalogue), seen as the last covenant, have a format similar to that of the Hittite's covenant. The Hittite covenant that circulated in $14^{\text {th }}-13^{\text {th }}$ centuries B.C.E., starts with a prologue explaining the existence of a god with his virtuous works for the people, and then continues with a series of commandments for the people. Among these is a ban on making contact with the enemies of the king, especially subjugated kings. When we compare this to the Ten Commandments, we must conclude that the latter also begins with a prologue: 'I am the Lord your God ... making many virtuous works'. This is followed by prohibition of polytheism and ends in six edicts regulating Israelite life. The six edicts express two fundamental things, the justice and truthfulness that later on became the most important material of prophetical preaching. For Wahono, the Ten Commandments in the Old Testament show a special relationship between God and humankind, and it is also an authoritative text in Christianity. In this way Christianity is different from other religions. ${ }^{14}$

\footnotetext{
12 Wahono 2001:106.

13 Wahono 2001:108.

14 Wahono 2001:113-114. To illustrate the source theory as mentioned by Wahono, we
} 
Wahono also states that the Israelites as a religious community received two privileges. Firstly, the covenant, which is an amazing benevolence, showing a close relationship between God and the Israelites. Secondly, through the covenant God expresses His caring for the Israelites who were being oppressed. He is willing to continuously love and be faithful to the Israelites (Exodus 34:6-7). However, the covenant which was given only once, has to be kept and obeyed by the Israelites from generation to generation (Deuteronomy 5:2-3).$^{15}$

\section{Eben Nuban Timo: Moses as the agent of change}

Dr. Eben Nuban Timo (born in Bimous, Timor Amarasi 1965) is the chief moderator of the Synod of the Protestant Evangelical Church in Timor (2007-2011), which has 1.2 million members. Regularly, he publishes sermons in the bimonthly magazine Tunas dari Tanah Kering [A Sprout out of Dry Ground] published by GMIT with a circulation of more than 10,000. He also wrote many books and articles and one of these is Pemberita Firman Pencinta Budaya [Preacher of the Word; Lover of Culture].

Nuban Timo assesses Moses as having a feeling of working alone. Therefore he needed teamwork to assist him. He also felt that he was getting old and weak. Therefore he required younger and stronger leaders to lead the Israelites to face challenges and troubles during their journey through the desert and wilderness (Numbers 11:10-15). ${ }^{16}$ This is why Moses was commanded by God to appoint seventy elders who were smart and strong.

In another place Nuban Timo, quoting Numbers 12:1-16 as the base of his interpretation, states that Moses did not list Aaron and Miriam as members of the seventy elders. This statement is rather strange because it deviates from the original biblical text. But then Nuban Timo asserts that Moses' siblings were not

quote Singgih who characterizes it as follows: the Jahvist (J) written in Jerusalem is linked historically to the palace of Solomon or afterwards and is from the $10^{\text {th }}$ century B.C.E. The Elohist (E) composed in Northern Israel and is from the $8^{\text {th }}$ century B.C.E. Finally, the Priestly writer $(\mathrm{P})$ writing in the period of Exile in Babylon or afterwards is from $6^{\text {th }}$ century B.C.E. It is all still under debate. Singgih, citing Rolf Rendtorff, asserts that both J and E versions must be placed into the period of Exile. Singgih 1999:200-201.

15 Wahono 2001:111.

16 Nuban Timo 2007:24. 
appropriate for the work since the duty required capable persons, able to solve problems while wandering in the wilderness. Eventually, Moses was hated by Aaron and Miriam and this is the main reason behind the opposition of Miriam and Aaron to Moses who had married a Cushite. The opposition demonstrates a dramatic attempt to sabotage Moses' reformation process for the Israelites. For this, Nuban Timo offers a rhetorical question: If Moses was allowed to effect a change, what then was Aaron and Miriam position? Although Moses did not appoint his siblings Aaron and Miriam as members of the seventy elders, the siblings made a valuable contribution to Moses' services. ${ }^{17}$

\section{E. Ramadhani: Moses, the weak one by nature who was used by God}

The first Roman Catholic to be discussed here is Thomas Aquino Deshi Ramadhani (born in Jakarta 1966), a Jesuit who teaches Old Testament Studies at the Driyarkara Philosophical Seminary Jakarta (Sekolah Tinggi Filsafat Driyarkara Jakarta - STF Driyarkara Jakarta). Ramadhani studied at the GregorianUniversity and the Pontifical Biblical Institute of Rome and took his Ph.D. at the Jesuit School of Theology in Berkeley, California (2004). One of his shorter writings is "Harun, Korban Kelalaian Musa: Pergulatan Dialogis Maksud Semantik dalam Bilangan 12-20" [Aaron, the victim of Moses' Carelessness: A Dialogue Struggle of the Semantic Meaning in Numbers 12-20].

For Ramadhani, Moses is a great leader. His greatness began to grow when he was called by God to lead the Israelites to move from Egypt to the Promised Land. Ramadhani acknowledges that Moses is a great leader, but he also sinned against God in his daily life. Because of that he was forbidden to enter to the Promised Land. Although he is a sinner, God used him as His messenger to fulfil the promise of salvation. For Ramadhani, this position cannot be replaced by other people. In the light of this understanding he states that the Old Testament cannot be replaced by the New Testament, not even by Jesus. Through this statement, Ramadhani affirms that the fact that Moses is a man by nature does not ban him from the position of messenger or require that he be substituted by Jesus. Indeed, God's appointment of Moses who is naturally a human to carry out His mission, clearly indicates that God does not only use a man with human

17 Nuban Timo 2007:44. 
power and authority to carry out His mission but also a weak human being. Therefore, in doing theology, Christians are called upon to live up to biblical justice and fairness like that described here. ${ }^{18}$

Ramadhani then gives attention to the sinful acts of Moses as seen from the events of the exploration Canaan and the water coming from the rock. About the exploration of Canaan Numbers 13:2 writes: "Send some men to explore the land of Canaan, which I am giving to the Israelites. From each ancestral tribe send one of its leaders." Using Bakhtin's theory of literature as basically a representation of dialogue and debate, Ramadhani sees the verse as a piece of communication that relates God's command to Moses to explore the land. However Moses did not only declare God's command, but also added his semantics. ${ }^{19}$

Before departing, Moses commanded explorers to bring sample crops from the land to him soon after their exploration. There were two facts opposing each other from their reports. The first explorer team reported that the condition of the land was good: "It does flow with milk and honey!" (Numbers 13:27). A narrator informs us that they brought back the specimens of its fruits. Numbers 13:17b-20 writes: ${ }^{20}$

Go up through the Negev and on into the hill country. See what the land is like and whether the people who live there are strong or weak, few or many. What kind of land do they live in? Are they unwalled or fortified? How is the soil? Is it fertile or poor? Are there trees on it or not? Do your best to bring back some of the fruit of the land.

Ramadhani verifies that verses $17 \mathrm{~b}-20$ of Numbers 13 show God's intention to explore only the land. However, Moses, as the first speaker, added his own intention namely the people of the land had to be explored as well. The consequence of Moses' own additional intention should then be the responsibility of Moses. ${ }^{21}$

18 Ramadhani 2005:34.

19 Ramadhani uses the literary theory of Michael Bakhtin to read the text of Moses in the Old Testament. By this theory, Ramadhani gives attention to the utterance of the speaker. For him, it shows a semantic intention that composes a set of meanings and at the same time it also looks forward to a response. And by this way there will be a dialogic construction of consciousness. Ramadhani 2005:11.

20 Ramadhani 2005:16.

21 Ramadhani 2005:17. 
The second group that came with a report about the people of the land, as ordered by Moses, was punished with a plague and were destroyed by God (Numbers 14:11-12). Oddly, none of the Israelites complained to Moses. They should have pointed out that the great leader's semantic utterance was not from God. For Ramadhani, Moses knew already what would be the consequence of his falsehood, that was the destruction of the explorers. However, Moses took no steps to prevent the unwanted consequence of his order. He just prayed to God in order to forgive the sins of the Israelites. He even said that God was to punish the guilty (Numbers 14:17-19). So, Moses' words in verses 17-19 of Numbers 14 are a strong criticism directed onto himself. Moreover, this behaviour of Moses shows that he failed to be a responsible leader who should protect all the Israelites. Moses was also a coward who did not express his deep regret and did not take the risk of his utterance that caused that a group of his people died. ${ }^{22}$

About the second event, water flowing from the rock, Numbers 20:7 writes: "Take the staff, and you and your brother Aaron gather the assembly together. Speak to that rock before their eyes and it will pour out its water. You will bring water out of the rock for the community so they and their livestock can drink." After perceiving God's words as written in this verse, Moses said and acted as follows: "Listen, you rebels, must we bring you water out of this rock? Then Moses raised his arm and struck the rock twice with his staff." (Numbers 20:1011). Ramadhani shows three faults in Moses when he explained God's message to the Israelites. Firstly, Moses did not speak to the rock as said in Numbers 20:7. Instead, he spoke to the people: "Listen, you rebels, must we bring you water out of this rock?" Secondly, God commanded him to speak to the rock, but he just used his staff to strike the rock twice. Thirdly, 'speaking to the rock' should be done by the two brothers together but the words were then spoken by Moses alone. And his utterance should not be directed to the people but to the rock only. All this typical and repeated behaviour destroyed the partnership between Moses and Aaron, while the Israelites of course would be very happy to see them doing their tasks together. Even God implicitly endorsed that way through his words above. Sadly, Moses impressed us as a single fighter. But that is Moses who is naturally a human. ${ }^{23}$

\footnotetext{
22 Ramadhani 2005:22.

23 Ramadhani 2005:29-30.
} 


\section{F. Martin Harun: Moses as a liberator}

Martin Harun Olsthoorn (born 1940 in Haarlem, the Netherlands) is a Franciscan friar and professor in biblical theology at Driyarkara Philosophical Seminary (Sekolah Tinggi Filsafat Driyarkara - STF Driyarkara). He is also an active researcher in the Indonesian Biblical Institute (Lembaga Biblika Indonesia - LBI) linked to the Roman Catholic church in Indonesia and also in the Indonesian Bible Society (Lembaga Alkitab Indonesia - LAI) associated with the Indonesian Protestant churches. He has published widely on the theory and practice of biblical studies.

In a somewhat earlier writing Martin Harun gives a narrative exegesis about the person of Moses in the style of Liberation Theology. As he sees it, the story of Moses' childhood is intentionally added in the text of Deuteronomy 2 as it is also provided for Samson, Samuel, David and Jesus. But he states that this episode is more a legend than a real biography. Its aim is that Moses will play an important role in his people to come. In a textbook for students of theology, he sees Moses' name as originating from an Egyptian name, tut-moses, explained generally as the passive form of the Hebrew, masya, meaning 'drawn out' because the princess of Egypt drew the baby out from the water. Harun interprets 'the way to draw him out' as the symbol of Moses' later task when he lead Israelites out of Egypt through the Red Sea. ${ }^{24}$

When Moses grew older, he went out to where his own people were and"watched them at their hard labour. He saw an Egyptian beating a Hebrew, one of his people" (Exodus 2:11-12). According to Harun, verses 11-12 (and also 16) of Exodus 2 show that Moses grew and became more mature in justice and fairness. ${ }^{25}$ In these verses, Moses is portrayed as having empathy for people who are suffering. He has no attitude of racial and cultural discrimination. Because of his empathy for the suffering men, he involved himself in the three events that followed. Firstly, Moses involved himself in a fight between an Isra-

24 Harun 2004a:7.

25 Exodus 2:11, 'One day, after Moses had grown up, he went out to where his own people were and watched them at their hard labor'; 2:12, 'Glancing this way and that and seeing no one, he killed the Egyptian and hid him in the sand'; and 2:16, 'Now a priest of Midian had seven daughters, and they came to draw water and fill the troughs to water their father's flock.' 
elite and an Egyptian. He did it because he saw an imbalance between the two men in that fight so he helped the Israelite. Eventually, he killed the Egyptian (Exodus 2:11). Secondly, the next day he admonished the two Israelites who were fighting (Exodus 2:13). This case became a hot rumour that spread across the regions of Egypt soon afterwards. The chiefs in the royal palace also heard this rumour, so they planned to kill Moses. Knowing the royal palace's plan, Moses was afraid. He fled from Egypt, going away from the suffering people in his hometown. Thirdly, he met Jethro's daughters in Midian and provided help to them (Exodus 3:16). ${ }^{26}$

Moses left his hometown and stayed at Midian. There he not only got shelter and felt very secure but also got employment and even found his wife. Then he had a son named Gersom. This son's name, meaning 'as a refugee in the alien land', reminded him about his hometown so he always longed to go back. Gersom is also a name referring to Moses in preparation to be a liberator in future. $^{27}$

The next episode is the meeting between Moses and God at the burning bush (Exodus 3:2-4). Seemingly, Moses had no prior experience of such a theophany as he experienced at that moment. Hence he wanted to investigate what happened there. But God prevented him from examining the Lord the way he wanted to. God ordered him only to respect and fear Him (Exodus 3:5). For Harun, the method of exploration that Moses wanted to practise is often used by readers and interpreters today. Academic exegesis often applies a scientific approach to scrutinize the event of the burning bush and to conceive it as a natural phenomenon. Ultimately, their conclusion does not give us an idea about its real meaning.

According to Harun, the mystery of the theophany itself cannot be scrutinized through any scientific approach but only through respect and astonishment. ${ }^{28}$ At Sinai, however, Harun describes Moses as a political prophet who negotiated with God about the conditions for the Israelites to receive the covenant or not. In addition, he also prepared his people to obey the covenant and led them to the theophany (Exodus 19-20). Moses' activity, going up to and

\footnotetext{
26 Harun 2004a:7.

27 Harun 2004a:8.

28 Harun 2004a:9.
} 
down from Mount Sinai as written in Exodus 19:3, 7, 8, 20, 25 (Version P), shows his energetic role as mediator between God and the Israelites. After having appointed Moses as mediator, God gave him His laws. Soon afterwards, Moses distributed the laws to his people. ${ }^{29}$

\section{G. Y.M. Seto Marsunu: Moses never forgot his Hebrew origin.}

Y.M. Seto Marsunu was born in Kalasan, Yogyakarta, in 1975. He studied biblical theology in the St. Peter Pontifical Institute, Bangalore, India. He took his master's degree from there. Now, he is a secretary of the Indonesian Biblical Institute (Lembaga Biblika Indonesia - LBI) and organises Bible courses for the Roman Catholic parishes in Jakarta.

In the course material Allah Leluhur Kami; Tema-tema Teologis Taurat, [The God of our Forefathers. Theological themes from the Torah] Marsunu sees Moses living in Egypt and growing up as a young prince with other Egyptian princes. Nevertheless, he never forgot his Hebrew origin. He had compassion with his people who were forced to work at royal projects and he tried to liberate them. The main reason for Moses' empathy was his knowledge concerning Pharaoh's intention to destroy the Israelite population through forced work. However, the effort to liberate the oppressed people through Moses' violent approach is criticised by a fellow Hebrew. Exodus 2:14 writes: "The man said, Who made you ruler and judge over us? Are you thinking of killing me as you killed the Egyptian?" 30 Marsunu mentions that the Egyptian is an Egyptian foreman killed by Moses. In another book Lahirnya Umat Pilihan; Ulasan Keluaran 1-15, Marsunu describes Moses as showing his attitude of a political liberator in the murder incident. He also stresses Moses' plan to take away the corpse (Exodus 2:12) as the way to liberate the Israelites from the accusation of the Egyptian royal ruler. ${ }^{31}$

\footnotetext{
29 Harun 2004b:6-7.

30 Marsunu 2008:54-55.

31 Marsunu 2010:20-21.
} 


\section{H. Concluding Remarks}

Here, at least, is noted four significant things. The first note concerns Moses as God's servant in whom heused this title to empower his sole role among the Israelites as well as President Soekarno named himself pemimpin besar revolusi.In fact,President Soeharto also did the same thing. He had togo to Mecca for pilgrimage and obtained hajjin 1991. Hishajjwas strenghtened with his acceptance of his new first name given by King Fahd bin Abdulaziz Al Saud(1921-2005) of Saudi Arabia, that is, "Muhammad" (thus, his complete name now is Haji Muhammad Soeharto). According to many foreign observers, his pilgrimage was politically motivated. ${ }^{32}$ By this way, he would be protected from threat sand attack of the Islamic political opponents.

At the context of local politics nowadays, in Minahasa for instance, many politicians havingposition of "penatua" (elder) and "samas" (deacon) feel it lucky. Why? Because by the special service positions in the Minahasa Churchmake them easily to get voetersin the direct elections of local government heads and parliemens. Or in other words, they holding one of the positions widely have apportunity to win the election. ${ }^{33}$

The second one is on position of Moses as a great leader as the theologians told above. On this, some leaders of political parties in Indonesia have frequently showed it.There is an image of the most democratic leaders among their supporters, providing ample opportunity to their cadres for improving their career ladder in politics, standing amid them and defending their position with a convincing reason. However, the reason behind that image is that they have already felt secure, higher and more honorable with their position. Practically,even, they who decide the fate of the political career of anyone in their party. ${ }^{34}$ Like Moses, therefore, we consider themas leaders by nature who tend to misuse the power and authority given to them.

32 Azyumardi Azra 2006:96.

33 Rev. Piet Tampi, Chairman of the Synodof Minahasa Church, appealed to all elders and deacon selected not to usethe special service status asa political tool in general election. http:/ / www.harian-komentar.com/headlines-news/14383-tampi-status-penatua-syamasjangan-dipakai-kampanye.html

34 Aleksius Jemadu, Jakarta Globe, September 12, 2013:One of party leaders is Megawati showing her power higher than other cadres in the Indonesian Democratic Party of Struggle 
The third one is that portrayed by Christian theologians above, Moses used the issue of ethnicity(Hebrew origin) to garner support of the people of Israel. Using this issue to be one effective way for Moses to liberate his people from slavery in Egypt. Here, in Indonesia, are new modes of inter-ethnic coalition building and cooperation have emerged. This is most visible in the direct elections of local government heads that are held every five years in the country's 33 provinces and more than 500 districts. This is a gold occassion for Indonesian candidate stouse the ethnicity issue to gain support for their ambition. On the one hand, the image proclaimed intentionally that theyare ones of us (same ethnic/tribe) and,for that reason,theyhave a sense of and responsible for improving the poor lives of theirrelatives.Then, there has been an emerging body of evidence to suggest that voters in many regions tend to prefer voting for political candidates who come from their own ethnic group.However, the candidates also attend cultural activities of different groups and they choose campaign slogans that stress their commitment to diversity and pluralism. ${ }^{35}$

The last note is that noman is perfecteven though he is Moses, the leberator of Israel. But the important thing emphasized by Christian theologians above is in a state of imperfect human,God can use us to carry His mission out. Therefore, all our efforts hall not close the space for God to reveal His will. Therefore,let all of our good work be the ways to glorify God, not glorify our own self.

(PDIP), although Governor JokoWidodo, one of PDIP cadres, whose electability now is far higher than other presidential candidates. http://www.thejakartaglobe.com/opinion/despite-joko-widodos-popularity-megawati-will-likely-run-herself/. DownloadedonOctober 19, 2013.

35 Edward Aspinall, East Asia Forum, August 5, 2010:

In areas which are ethnically mixed, a new political image has emerged during these elections: the formation of cross-ethnic coalitions. For example, in the recent mayoral election in the city of Medan, the highly plural capital of North Sumatra, ten pairs of mayoral and deputy-mayor candidates contested the first round of the vote: every pair consisted of two individuals from different ethnic groups. This pattern is typical of multi-ethnic regions. http:/ / www.eastasiaforum.org/2010/08/05/the-taming-of-ethnic-conflict-in-indonesia/. DownloadedonOctober 19, 2013. 


\section{DAFTAR PUSTAKA}

Azra, Azyumardi, 2006, Indonesia, Islam, and Democracy Dynamics in a Global Context, Jakarta: Solistice Publishinghouse.

Harun, Martin, 2004a, Kisah Pembebasan (Keluaran 1-15) [The Story of Liberation: Exodus 1-15.], (Unpublished Teaching Materials for PhilosophyTheology students), Jakarta: STF Driyarkara.

2004b, Perjanjian Sinai [The Covenant at Sinai], (Unpublished Teaching Materials for Philosophy-Theology students), Jakarta: STF Driyarkara. 2005 'Tafsir Alkitab dalam Konteks Budaya Indonesia,' Forum Biblika, 17:6-16.

Hendrastomo, Grendi, 2009, “Demokrasi dan Politik Pencitraan" DIMENSIA, Volume 3, No. 2,September:1-14.

Marsunu, Y.M. Seto, 2008, Allah Leluhur Kami; Tema-tema Teologis Taurat, Yogyakarta: Kanisius.

2010, Lahirnya umat pilihan: Ulasan Keluaran 1-15, Yogyakarta: Kanisius.

NubanTimo, Eben, 2007, 'Daily Bread' column in the Magazine Tunas Baru, Kupang.

2009, 'Daily Bread' column in Magazine Tunas Dari Tanah Kering January - February, Kupang.

Ramadhani, Deshi, 2006, 'Harun, Korban Kelalaian Musa: Pergulatanan Dialogis Maksud Semantik dalam Bilangan 12-20' in: Kristiyanto, Eddy, Sinar Sabda dalam Prisma; Hermeneutika Kontekstual, Yogyakarta: Kanisius, hal. 7-39.

2007, Menguak Injil-Injil Rahasia, Yogyakarta: Kanisius 2007.

Singgih, E. G., 1999, Dunia yang Bermakna, Jakarta: Persetia.

2003, Doing Theology in Indonesia. Sketches for an Indonesian Contextual Theology, Manila: ATESEA.

Wahono, S. Wismoady, 2001, Di Sini Kutemukan, Jakarta: BPK GunungMulia.

\section{Internet:}

http:/ / www.thejakartaglobe.com/opinion/despite-joko-widodos-popularitymegawati-will-likely-run-herself/.

http:/ / www.eastasiaforum.org/2010/08/05/the-taming-of-ethnic-conflict-inindonesia/. DownloadedonOctober 19, 2013. 